\title{
Evaluation of Organic and Inorganic Dust Concentration in Different Mechanized Agricultural Operations for Wheat Crop
}

\author{
S. H. Shivpuje ${ }^{1 *}$, A. K. Mehta ${ }^{1}$ D. V. Patil ${ }^{2}$ and P. A. Dharaiya ${ }^{1}$ \\ ${ }^{1}$ Department of FMPE, College of Technology and Engineering, \\ MPUA\&T, Udaipur (Raj.), India \\ ${ }^{2}$ Department of FMPE, College of Agricultural Engineering and Technology, \\ VNMKV, Parbhani (MH), India \\ *Corresponding author
}

\section{A B S T R A C T}

\begin{tabular}{l} 
Ke y w o r d s \\
$\begin{array}{l}\text { Dust Concentration, } \\
\text { Wheat, Dust } \\
\text { Monitor, OSHA, } \\
\text { environmental } \\
\text { parameters }\end{array}$ \\
\hline Article Info \\
$\begin{array}{l}\text { Accepted: } \\
\text { 22 June } 2020 \\
\text { Available Online: } \\
\text { 10 July } 2020\end{array}$
\end{tabular}

\section{Introduction}

Dust is generated as a result of agricultural machine operations in the field mostly by machine-soil and machine-plant interactions. Agriculture workers breathe the generated dusts during the operation. Dust also interacts with human body as the skin is exposed to dust particles. Dusts generated in agricultural activities could be classified as inorganic
Agricultural dusts are generated due to crop production activities such as ploughing, seed bed preparation, sowing, harvesting and threshing. The present study was undertaken for evaluation of organic and inorganic dust concentration in different agricultural operations in Wheat crop cultivation. The dust concentration at two locations (near to operator seat on tractor and at by-stander position) for ploughing, seed bed preparation, sowing and harvesting operations. Whereas, the dust concentration for threshing operation were taken at three locations viz. feeding chute, bhusa outlet and grain outlet positions. A real - time personal dust monitor was used to measure the dust levels after every $15 \mathrm{~min}$ of operation. In this measurement $2.5 \mu \mathrm{m}, 10 \mu \mathrm{m}$ and TSP size sampling head were used. The measured dust concentration levels were compared with standard exposure limits defined by OSHA. The range of environmental parameters such as Temperature $\left({ }^{0} \mathrm{C}\right)$, Relative humidity (\%) and Wind speed $(\mathrm{m} / \mathrm{sec})$ were also measured by using WBGT monitor. Moisture content of soil $(\%)$ and tractor forward speed $(\mathrm{km} / \mathrm{h})$ were also measured for field operations. It was found that, all the operations, the dust concentrations were well below the standard exposure limits in wheat production. 
and endotoxins (Snbosh, 1994). These dust particles range in size from $<0.01$ to $100 \mu \mathrm{m}$, with up to 40 percent in the respirable range. Dust sizes in the air could vary in the range of 1 - $30 \mu \mathrm{m}$ (Alsan, 1998). Dusts larger than 10 $\mu \mathrm{m}$ are considered to be coarse dusts, which are blocked in the upper air passages in the body. Dust particles smaller than $10 \mu \mathrm{m}$ are fine dusts and can penetrate into lower air passages in the human body. Dust particle size below $5 \mu \mathrm{m}$ may reach alveolar region of the lungs. Some portions of the fine dust are cell penetrating and can reach terminal bronchioles as shown in Fig. 1.

For all farmers the relative heart rate increase during working, resulting in increased respiration which enhances inhaling of dusts at the workplace (Christensen et al., 1992). According to Reilly (1981), operators working in agriculture faced allergies four times more as compared to a control group. Respiratory problems turned out to be the second most common diseases that the farmers suffer and tractor and combine operators experienced bronchioles two times more than other agricultural workers. Respiratory problems were observed in 25 percent of the agricultural operators. The present study was taken to determine the dust concentration levels in different agricultural operations.

\section{Materials and Methods}

The study was conducted at Instructional farm of College of Technology and Engineering, Udaipur where wheat crop was grown in sandy loam soil of Rabi season. Dust concentrations were measured during all operations such as ploughing, seed-bed preparation, sowing, harvesting and threshing in the entire crop growing period (November 13 to April 14). Total five locations were selected, two locations that were near to operator seat on tractor and at by-stander position in ploughing, seed bed preparation, sowing and harvesting operations and other three locations near grain outlet, near feeding chute and bhusa outlet in threshing operation. The wind velocity $(\mathrm{m} / \mathrm{sec})$, temperature $\left({ }^{\circ} \mathrm{C}\right)$, and relative humidity (percent), moisture content of soil (percent) and tractor forward speed $(\mathrm{km} / \mathrm{h})$ during each operation were also recorded. The environmental heat stress index was measured with Quest 36 heat stress monitor. Three different sized sampling heads $2.5 \mu \mathrm{m}, 10 \mu \mathrm{m}$ and TSP were used to measure the dust concentration with HAZ Dust sampler (EPAM 5000). A total of thirty six measurements were taken for three dust size sampling heads with three replications each for each of the operations. This study was conducted to characterize potential exposure to dust during ploughing, seed bed preparation, sowing, harvesting and threshing operations of wheat production. The dust measurements near to operator seat in harvesting and near grain outlet in threshing operation are shown in Fig. 2 and Fig. 3 respectively.

\section{Standard exposure limits of dust concentration}

The measured dust levels were compared with standard exposure limits given by Occupational Safety and Health Administration (OSHA, 2010) and American Conference of Governmental Industrial Hygienists (ACGIH) (Kirkhorn, 2000). The standard exposure limits are given in (Table.1)

\section{Results and Discussion}

\section{Environmental parameters}

The dry bulb temperature in ploughing, seed bed preparation, sowing and harvesting operations varied from $25-29^{\circ} \mathrm{C}, 30-32^{\circ} \mathrm{C}, 30$ $32^{\circ} \mathrm{C}$ and $36-40^{\circ} \mathrm{C}$, respectively. The relative 
humidity in ploughing, seed bed preparation, sowing and harvesting operations was recorded from 30-34 percent, $25-28$ percent, 25-28 percent and 20-22 percent, respectively. The wind speed in ploughing, seed bed preparation, sowing and harvesting operations was observed from $0.3-0.5 \mathrm{~m} / \mathrm{s}, 0.3-0.7 \mathrm{~m} / \mathrm{s}$, $0.4-0.8 \mathrm{~m} / \mathrm{s}$ and $0.4-1.2 \mathrm{~m} / \mathrm{s}$, respectively. The moisture content of soil in ploughing, seed bed preparation, sowing and harvesting operations varied from 16-20 percent, 12-16 percent, 12-16 percent and 6-8 percent, respectively. The tractor forward speed in ploughing, seed bed preparation, sowing and harvesting operations was maintained such as $5.0-5.2 \mathrm{~km} / \mathrm{h}, 5.3-5.5 \mathrm{~km} / \mathrm{h}, 5.0-5.2 \mathrm{~km} / \mathrm{h}$ and $4.0-5.0 \mathrm{~km} / \mathrm{h}$, respectively.

Table.1 Standard exposure limits

\begin{tabular}{|c|c|c|}
\hline Dust Type & ACGIH $\left(\mathbf{m g} / \mathbf{m}^{\mathbf{3}}\right)$ & OSHA $\left(\mathbf{m g} / \mathbf{m}^{\mathbf{3}}\right)$ \\
\hline Total dust & 10 & 15 \\
\hline Respirable dust & 3 & 5 \\
\hline
\end{tabular}

Table.2 Concentrations near operator's seat and at by- stander position for $\mathrm{PM}_{2.5}$

\begin{tabular}{|c|c|c|}
\hline Location & Operation & Dust concentration measured $\left(\mathrm{mg} / \mathrm{m}^{3}\right)$ \\
\hline \multirow{4}{*}{ Operator seat } & Ploughing & 0.512 \\
\hline & Seed bed preparation & 0.621 \\
\hline & Sowing & 0.773 \\
\hline & Harvesting & 1.134 \\
\hline \multirow{4}{*}{$\begin{array}{l}\text { By-stander } \\
\text { position }\end{array}$} & Ploughing & 0.232 \\
\hline & Seed bed preparation & 0.237 \\
\hline & Sowing & 0.261 \\
\hline & Harvesting & 0.325 \\
\hline \multicolumn{2}{|c|}{ CV (\%) } & 4.70 \\
\hline \multicolumn{2}{|c|}{ CD at $5 \%$} & 0.0406 \\
\hline
\end{tabular}

Table.3 Dust concentrations at operator seat and at by stander position for $\mathrm{PM}_{10}$

\begin{tabular}{|l|c|c|}
\hline Location & Operation & Dust concentration measured $\left.\mathbf{~} \mathbf{m g} / \mathbf{m}^{\mathbf{3}}\right)$ \\
\hline \multirow{3}{*}{ Operator seat } & Ploughing & 0.524 \\
\hline \multirow{3}{*}{ By stander position } & Seed bed preparation & 0.626 \\
\cline { 2 - 3 } & Sowing & 0.942 \\
\cline { 2 - 3 } & Harvesting & $\mathbf{1 . 8 4 5}$ \\
\cline { 2 - 3 } & Ploughing & 0.424 \\
\cline { 2 - 3 } & Seed bed & 0.485 \\
& preparation & 0.623 \\
\hline & Sowing & $\mathbf{0 . 8 5 5}$ \\
\hline & Harvesting & $\mathbf{9 . 0 3}$ \\
\hline & CD at 5 \% & $\mathbf{0 . 1 2 0 3}$ \\
\hline
\end{tabular}


Table.4 Total dust concentrations at operator seat and at by stander position in different operations

\begin{tabular}{|c|l|c|}
\hline Location & Operation & Dust concentration measured $\left.\mathbf{( m g} / \mathbf{m}^{\mathbf{3}}\right)$ \\
\hline \multirow{3}{*}{ Operator seat } & Ploughing & 0.753 \\
\cline { 2 - 3 } & Seed bed preparation & 1.163 \\
\cline { 2 - 3 } & Sowing & 3.137 \\
\cline { 2 - 3 } & Harvesting & $\mathbf{3 . 5 7 7}$ \\
\hline \multirow{3}{*}{$\begin{array}{l}\text { By stander } \\
\text { position }\end{array}$} & Ploughing & 0.441 \\
\cline { 2 - 3 } & Seed bed preparation & 0.468 \\
\hline \multirow{2}{*}{ CV (\%) } & Sowing & 0.939 \\
\hline CD at 5 \% & Harvesting & $\mathbf{1 . 6 4 3}$ \\
\hline
\end{tabular}

Table.5 Dust measurements of $\mathrm{PM}_{2.5}$ in threshing operation

\begin{tabular}{|l|l|c|}
\hline Operation & Locations & Dust concentration measured $\left(\mathbf{m g} / \mathbf{m}^{\mathbf{3}}\right)$ \\
\hline \multirow{3}{*}{ Threshing } & Grain outlet & 0.076 \\
\cline { 2 - 3 } & Feeding chute & 0.356 \\
\cline { 2 - 3 } & Bhusa outlet & $\mathbf{0 . 9 1 0}$ \\
\hline & CV $(\%)$ & $\mathbf{5 . 5 7}$ \\
\hline & CD at 5 \% & $\mathbf{0 . 0 4 5 3}$ \\
\hline
\end{tabular}

Table.6 Dust measurements of $\mathrm{PM}_{10}$ in threshing operation

\begin{tabular}{|l|l|c|}
\hline Operation & Location & Dust concentration measured $\left(\mathbf{m g} / \mathbf{m}^{\mathbf{3}}\right)$ \\
\hline \multirow{3}{*}{ Threshing } & Grain outlet & 0.123 \\
\cline { 2 - 3 } & Feeding chute & 0.537 \\
\cline { 2 - 3 } & Bhusa outlet & $\mathbf{0 . 8 5 4}$ \\
\hline & CV $(\mathbf{\%})$ & 12.40 \\
\hline & CD at 5 \% & 0.1138 \\
\hline
\end{tabular}

Table.7 Total dust concentration at three locations in threshing operation

\begin{tabular}{|c|l|c|}
\hline Operation & Location & Dust concentration $\left(\mathbf{m g} / \mathbf{m}^{\mathbf{3}}\right)$ \\
\hline \multirow{3}{*}{ Threshing } & Grain outlet & 0.165 \\
\cline { 2 - 3 } & Feeding chute & 0.854 \\
\cline { 2 - 3 } & Bhusa outlet & $\mathbf{1 . 6 4 3}$ \\
\hline \multirow{3}{*}{ CV $(\%)$} & $\mathbf{5 . 1 1}$ \\
\hline & CD at 5 \% & $\mathbf{0 . 0 8 2 4}$ \\
\hline
\end{tabular}


Fig.1 Dust particle sizes and dust penetration in the respiratory system (Reilly, 1981)

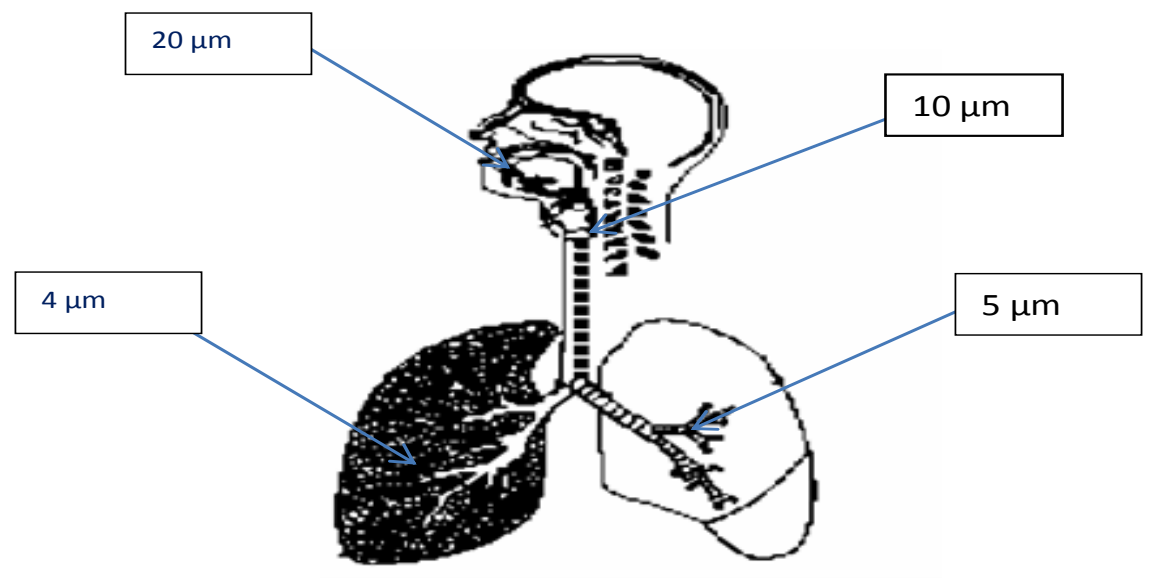

Fig.2 Dust concentration measurement in harvesting

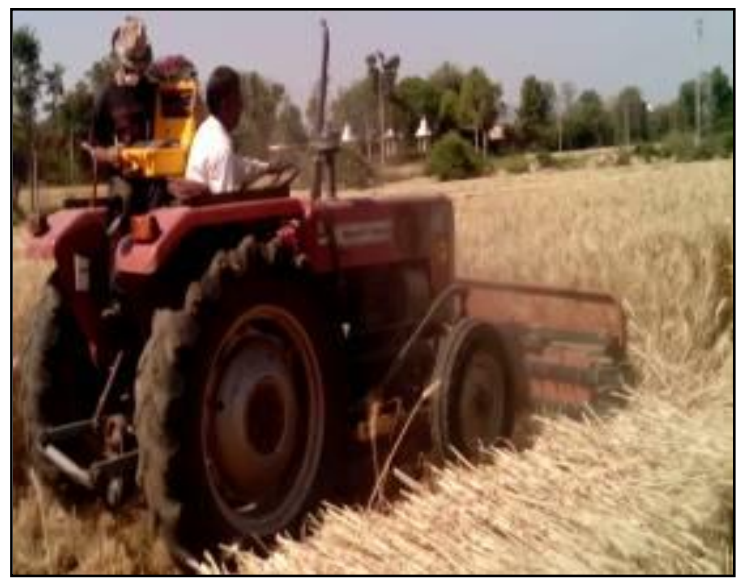

Fig.3 Dust concentration measurement in threshing

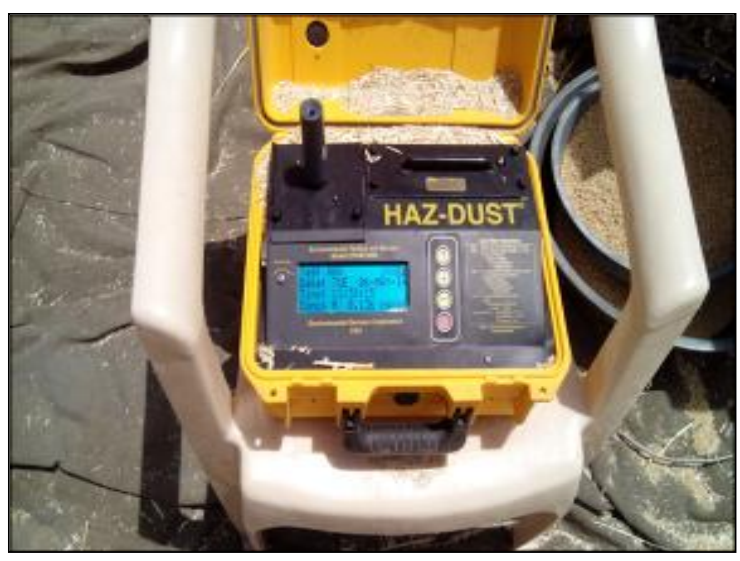


Assessment of dust concentration during different agriculture operation

Dust concentration were measured in field operations with $2.5 \mu \mathrm{m}\left(\mathrm{PM}_{2.5}\right), 10 \mu \mathrm{m}$ $\left(\mathrm{PM}_{10}\right)$ and TSP sampling head at both near operator's seat and at by-stander position in ploughing, seed bed preparation, sowing and harvesting operations.

\section{Concentration of $2.5 \mu \mathrm{m}$ particle size dust in different operations}

Dust concentrations were measured with 2.5 $\mu \mathrm{m}$ size sampling head at operator seat and at by-stander position in different agricultural operations (Table.2).

The highest dust concentration was recorded as $1.134 \mathrm{mg} / \mathrm{m}^{3}$ at operator seat in harvesting operation. High dust concentration in harvesting operation may be because of organic dust generated due to high speed cutting of crop. Ploughing operation was recorded minimum dust concentration because of moisture presence in soil due to presowing irrigation. Both locations show the same pattern of dust concentration.

Concentration of $\mathbf{1 0} \mu \mathrm{m}$ particle size dust in different operations

Dust concentrations were measured with 10 $\mu \mathrm{m}$ dust size sampling head at operator seat and at by stander position in different agricultural operations (Table.3). The highest dust concentration was rescored as 1.845 $\mathrm{mg} / \mathrm{m}^{3}$ at operator seat in harvesting operation.

As compared to ploughing, seed bed preparation and sowing operation dust concentration in harvesting operation of $\mathrm{PM}_{10}$ size at operator seat was found more due to the presence of organic dust in harvesting operation as compared to other three operations.
Concentration of Total dust in different operations

Dust concentrations were measured with TSP dust size sampling head at operator seat and at by-stander position in different agricultural operations (Table.4). The highest dust concentration was rescored as $3.577 \mathrm{mg} / \mathrm{m}^{3}$ at operator seat in harvesting operation. It was found that, the organic dust concentration was increased due to high speed crop cutting.

Dust concentrations at three locations in threshing operations

Dust concentrations in Wheat threshing operation were measured at three locations near grain outlet, near feeding chute and near bhusa outlet for three dust samples viz. $\mathrm{PM}_{2.5}$, $\mathrm{PM}_{10}$ and TSP.

\section{Concentration of $2.5 \mu \mathrm{m}$ particle size dust} in threshing operation

In threshing operation, there was significant effect on dust concentration in three different locations (Table.5). For $2.5 \mu \mathrm{m}$ dust particulates, the mean dust concentration near grain outlet, near feeding chute and near bhusa outlet were recorded as $0.076 \mathrm{mg} / \mathrm{m}^{3}$, $0.356 \mathrm{mg} / \mathrm{m}^{3}$ and $0.910 \mathrm{mg} / \mathrm{m}^{3}$, respectively in threshing operation. In comparison to grain outlet and feeding chute, the bhusa outlet had highest dust concentration measured as 0.910 $\mathrm{mg} / \mathrm{m}^{3}$ with $2.5 \mu \mathrm{m}$ size sampling head in threshing operation.

\section{Concentration of $10 \mu \mathrm{m}$ particle size dust} in threshing operation

For $10 \mu \mathrm{m}$ dust particulates, in threshing operation the mean dust concentration near grain outlet, near feeding chute and near bhusa outlet were recorded as $0.123 \mathrm{mg} / \mathrm{m}^{3}$, $0.537 \mathrm{mg} / \mathrm{m}^{3}$ and $0.854 \mathrm{mg} / \mathrm{m}^{3}$, respectively (Table.6). In comparison to grain outlet and 
feeding chute, the highest dust concentration was measured as $0.854 \mathrm{mg} / \mathrm{m}^{3}$ near bhusa outlet for $\mathrm{PM}_{10}$ in threshing operation.

\section{Total dust concentration in threshing operation}

For TSP dust particulates, the mean dust concentration near grain outlet, near feeding chute and near bhusa outlet were recorded as $0.165 \mathrm{mg} / \mathrm{m}^{3}, 0.854 \mathrm{mg} / \mathrm{m}^{3}$ and $1.643 \mathrm{mg} / \mathrm{m}^{3}$, respectively (Table.7).

The organic dust was generated from ploughing, seed bed preparation, sowing and harvesting operations and the inorganic dust was from threshing operation. The organic dust concentration from the harvesting operation was found very high in both cases of near to operator and by-stander positions among all the operations for three dust samplers. The highest inorganic dust concentration was recorded at bhusa outlet in threshing operation among three locations and for the all dust sizes. It was revealed that dust concentration whether organic or inorganic was found below the standard exposure limit of $3 \mathrm{mg} / \mathrm{m}^{3}$ for respirable dust as per the ACGIH.

\section{References}

Nieuwenhuijsen M. J. et.al. (1998). Determinants of personal dust exposure during field crop operations in California agriculture, American Industrial Hygiene Association Journal, 5(1): $9-13$.

Nieuwenhuijsen M. J., et.al (1998). Exposure to dust and its particle size distribution in California agriculture. American Industrial Hygiene Association Journal, 59(1): 34-38.

Aybek A.. et.al. (2007). Dust exposures in tractor and combine operations in Eastern Mediterranean, Turkey. Journal of Environmental Biology, 28(4): 839844.

Chhuneja N. K. (2009). Assessment of available dust protectors for protection to combine harvester operators. Development in Agricultural and Industrial Ergonomics, (1): 93-98.

Arslan S., et.al (2010). Measurement of Personal $\mathrm{PM}_{10}, \quad \mathrm{PM}_{2.5}$ and $\mathrm{PM}_{1}$ exposures in tractor and combine operations and evaluation of health disturbances of operators. Journal of Agricultural Sciences, 16: 104-115.

Pandirwar A. P., et.al (2010). Assessment of dust level in manual harvesting and threshing of wheat. M.Tech Thesis. Division of Agricultural Engineering, Indian Agricultural Research Institute, New Delhi.

Ghatge J.S. (2012). Study the dust concentration in the environment of flour mill and pulse mill and its comparison with the standard exposure limits. Unpublished M. Tech thesis. Department of farm machinery and power engineering, MPUAT Udaipur.

Selçuk A et.al (2012). Particulate matter exposure in agriculture. Licensee INTECH. This is an open access chapter. Website (http://creativecommons.org/licenses/by 13.0). Swedish National Board of Occupational Safety and Health, SNBOSH (1994). Organic Dust in Agriculture. General recommendations of the SNBOSH on organic dust in Agriculture Adopted 15th June 1994. Available at http: /www.av.se/document in English/legislations/eng 9411. pdf.

Aslan, Z. 1998. Sarayc $>k-S a r>h a n$ Granitoyidleri (Bayburt) ve Çevre Kayaçlar $\gg n ` n$ Petrolojisi, Jeokimyas $>$ ve Sarıhan Granitoyidinin Jeokronolojik «ncelenmesi [Petrology-Geochemistry of Sarayc $>k S a r>h a n$ Granitoids and Their Country Rocks and 
Geochronology of Sarhan Granitoid. $\mathrm{PhD}$ Thesis, Karadeniz Technical University, Trabzon [in Turkish with English abstract.

Christensen et al., 1992. et.al. Maize polyubiquitin genes: structure, thermal perturbation of expression and transcript splicing, and promoter activity following transfer to protoplasts by electroporation. Plant Molecular Biology. 18(4):675-89.

O'reilly, K. (1981), A Technique Of Diathermy Sclerosis Of Varicose Veins. Australian and New Zealand Journal of Surgery, 51: 379-382.

\section{How to cite this article:}

Shivpuje, S. H., A. K. Mehta, D. V. Patil and Dharaiya, P. A. 2020. Evaluation of Organic and Inorganic Dust Concentration in Different Mechanized Agricultural Operations for Wheat Crop. Int.J.Curr.Microbiol.App.Sci. 9(07): 2806-2813. doi: https://doi.org/10.20546/ijcmas.2020.907.331 